\title{
ORIENTALISM AND THE RHETORIC OF THE FAMILY: JAVANESE SERVANTS IN EUROPEAN HOUSEHOLD MANUALS AND CHILDREN'S FICTION $^{1}$
}

\author{
Elsbeth Locher-Scholten
}

Of all dominated groups in the former colonies, domestic servants were the most "subaltern." Silenced by the subservient nature of their work and the subordinated social class they came from, Indonesian or Javanese servants in the former Dutch East-Indies were neither expected nor allowed to speak for themselves. Neither did they acquire a voice through pressures in the labor market, as was the case with domestic servants in twentiethcentury Europe. ${ }^{2}$ Because of the large numbers of Indonesian servants, the principle of supply and demand functioned to their disadvantage. For all these reasons, it is impossible to present these servants' historical voices and experiences directly from original source material.

What we can do is reconstruct fragments of their social history from circumstantial evidence (censuses). Moreover, in view of the quantity of fictional sources and the growing interest in the history of colonial mentalities, we can analyze the Dutch narratives which chronicle the colonizer-colonized relationship. It is possible to reconstruct pictures of Indonesian servants by decoding these representations, although we should keep in mind that

\footnotetext{
${ }^{1}$ A first draft of this article was presented to the Ninth Berkshire Conference of the History of Women, Vassar College, June 1993. I want to thank the audience as well as Sylvia Vatuk, Rosemarie Buikema, Frances Gouda, Berteke Waaldijk and the anonymous reviewers of this journal for their useful comments on earlier drafts.

2 Since the Vassar historian Lucy Maynard Salmon published the first study of domestic service in the United States in 1890, the history of American and European domestic service has become a well-documented field of historical analysis. See for instance, Faye E. Dudden, Serving Women. Household Service in Nineteenth Century America (Middletown, Conn.: Wesleyen University Press, 1983); Theresa M. McBride, The Domestic Reoolution. The Modermisation of the Household Service in England and France 1820-1920 (London: Croom Helm, 1976); Uta Ottmüller, Die Dienstbotenfrage. Zur Sozialgeschichte der doppelten Ausnutzung von Dienstmädchen im deutschen Kaiserreich (Münster: Verlag Frauenpolitik, 1978), and bibliographies. For the Netherlands: Barbara Henkes and Hanneke Oosterhof, Kaatje ben je boven? Leven en werken van Nederlandse dienstbodes 1900-1940 (Nijmegen: SUN, 1985).
} 
this tells us more about the colonial mentality than about the servants themselves. Representations of domestic servants are part of the Orientalist tradition, i.e. of Western ideas about the "East." 3 They may serve as an illustration of Western constructions of domestic servants, of gender, and of race and ethnicity. In the household different variations of race (Dutch and Eurasian/Indonesian), social class, and gender confronted each other, and illustrated the complicated patterns of the colonial divide.

Colonial society produced colorful images and multiple stories of its colonized subjects, which have become the topic of scholarly scrutiny in their own right. In those images white superiority and race were compelling factors. As Ann Stoler has convincingly shown, gender also figured prominently in these images. ${ }^{4}$ Indigenous women were part of the selfdefinition and self-delineation, not only of individual white/European women but also of the internal hierarchy of white colonial society. Gendered imagery and behavioral prescriptions regarding white and indigenous women determined white group relations and sustained colonial rule. Depictions of the colonized reflected representations of the colonizer, individually, socially, and politically.

Following those studies, I intend to explore the imagery female colonial authors used in portraying Javanese domestic servants in the former Dutch East-Indies, during the heyday of Dutch colonialism, the period from 1900, when a new modernization policy (the so-called Ethical policy) was being introduced, until 1942, when Japan conquered the Archipelago. What do the representations of the domestic servants of that time tell us about race and gender relations at home, in the personal sphere where women wielded the scepter? Were women more race-conscious or openly racist than men, a hotly debated issue in current colonial historiography? ${ }^{5}$ I want to argue first that the female discourse on servants tallied with the male discourse on the colonized, as voiced in the political arena; second that this discourse on servants articulated both "Orientalism" and a rhetoric of the family, two attitudes which were only apparently paradoxical; and finally that the rhetoric of the family functioned as a rhetoric of concealment, hiding differences of race, class, and gender.

Two kind of sources, both constructed mainly by colonial women, are informative in this respect: 1 . the domestic manuals and introductory textbooks for new colonial residents; 2. children's literature, focusing on the home. Both sources are highly prescriptive and normative; they provide us with twentieth-century ideas and ideals concerning the relationship between Europeans and their servants, dealing more with theory than with practice and "reality." It may result in interesting paradoxes and tensions between both (see below). In

${ }^{3}$ E. Said, Orientalism (3rd imprint, London and Harmondsworth: Penguin Books, 1987).

${ }^{4}$ See the impressive work of Ann Stoler, especially her article "Making Empire Respectable: The Politics of Race and Sexual Morality in 20th Century Colonial Cultures," American Enthnologist 16 (1989): 26-51. This article also appeared in J. Breman ed., Imperial Monkey Business. Racial Supremacy in Social Darwinist Theory and Colonial Practice (Amsterdam: VU University Press, 1990), pp. 35-70. I used this edition.

5 See K. Ballhatchet, Race, Sex and Class under the Raj. Imperial Attitudes and Policies and their Critics 1793-1905 (London: Weidenfeld and Nicolson, 1980); Rudy Kousbroek, "De Mems in de koloniale samenleving," in Deugd en ondeugd. Jaarboek voor vrouwengeschiedenis 13, ed. Josine Blok et al. (Amsterdam: IISG, 1993), pp. 149-62; on counter-arguments, see Mieke Aerts, "Gemengde gevoelens bij gemengde berichten uit de Oost," in ibid., pp. 163-74; Margaret Strobel, "Gender and Race in the Nineteenth-and Twentieth-Century British Empire," in Becoming Visible. Women in European History, ed. R. Bridenthal, C. Koonz, and S. Stuard (Boston: Houghton Mifflin, 1987), pp. 375-98; Stoler, "Making Empire Respectable"; Claudia Knapman, White Women in Fiji 18351930. The Ruins of Empire? (Sydney: Allen and Unwin, 1986); Helen Callaway, Gender, Culture and Empire. European Women in Colonial Nigeria (Houndsmill, Basingstoke and London: MacMillan Press, 1987); L. E. Clerkx and W. F. Wertheim, Living in Deli; Its Society as Imaged in Colonial Fiction (Amsterdam: VU University Press, 1991). 
the framework of a history of the colonial mentality, especially of women, these prescribed notions offer in my opinion the most illuminating entrance to the subject. I did not turn to adult fiction, memoirs, or autobiographical writings here. Hence, the interesting role of the indigenous housekeeper (nyai) is not dealt with. 6 She was not a regular part of the twentieth-century European household and does not figure in the sources mentioned above.

Sources always reflect the position of their authors, these sources even more so, for Western literature on Indonesia has always been of a highly "autobiographical quality," as James Rush has recently stated. ${ }^{7}$ The authors belonged to the so-called European population group and were either totok (born in the Netherlands) or Indisch (which included both Eurasians and white families living already for generations in the Indies). They were a tiny minority (less than 0.4 percent) among the 60 million Indonesians in 1930 and were heavily concentrated on Java ( 80 percent). ${ }^{8}$ In 1930 half of the European families were of a totok character, half of Indisch descent. Both groups identified themselves within the European category. I will follow their use of the term. One might expect a difference in positions between female authors of totok or Indisch descent, but in the sources this cannot be discerned.

For these authors were all part and parcel of the process of Westernization of colonial society that took place in the first half of the twentieth century. A Tropisch Nederland ("Netherlands in the tropics") 9 developed in the interwar years. This process of "totokization" or Westernization was heavily influenced by a growing influx of Dutch totok men and women. ${ }^{10}$ Their (temporary) immigration was made possible by improved infrastructure and developments in the field of hygiene and health, education, and sports, which these immigrants in turn supported and developed. It strongly affected the culture of the colonial community. Newcomers from the Netherlands had to be educated for their future life in the Indies through books or other means; while at the same time they imported contemporary Western ideas and theories about family life and the household, considered essential for their well-being and welfare. These cultural "exchanges," lessons on the East and imprints from the West, are found in the domestic manuals as well as in children's fiction.

\footnotetext{
${ }^{6}$ For the nyai, see Tessel Pollmann, "Bruidstraantjes. De koloniale roman, de njai en de apartheid," in Vrouwen in de Nederlandse koloniën. Zevende jaarboek voor vrouwengeschiedenis (1986), ed. Jetske Reijs et al. (Njmegen: SUN, 1986), pp. 98-125; Nicole Lucas "Trouwverbod, inlandse huishoudsters en Europese vrouwen. Het concubinaat in de planterswereld aan Sumatra's Oostkust," in ibid., pp. 78-97; Elsbeth Locher-Scholten, "The nyai in Colonial Deli: A Case of Supposed Mediation," in Women and Mediation in Indonesia, ed. Sita van Bemmelen et al. (Leiden: KITLV Press, 1992), pp. 265-80.

7 James R. Rush, "Journeys to Java: Western Fiction about Indonesia 1600-1980," in Asia in Western Fiction, ed. R. W. Winks and J. R. Rush (Honolulu: University of Hawaii Press, 1991), p. 156.

8 Volkstelling 1930. VI. Europese bevolkingsgroep (Batavia: Landsdrukkerij, 1936), pp. 23, 25, 40, 68, 70, 78, 79. According to the census 21 percent ( 50,000 of the 208,000 Dutch Europeans) belonged to the totokgroup; the difference between this 20 percent and the 50 percent totok-headed households was to a large extent determined by the number of children born in the Indies to totok parents. (Ibid., p. 68.) The so-called European population group consisted in 1930 of Dutch citizens (either born in Holland or the Indies, either "white" or of mixed, Eurasian descent, 87 percent), as well as other Westerners (British, French, etc., 5 percent) and "legalized" Indonesians, Japanese, Filipinos, Thais, Egyptians (8 percent). When mentioned here, "Europeans" refers to the Dutch group.

${ }^{9}$ See the title of the famous Atlas van tropisch Nederland (Batavia: Topografische Dienst, 1938), as an illustration of this development.

${ }^{10}$ The sex ratio among Europeans changed considerably between 1880 and 1930: from 471 women per 1,000 men (1880) to 636 per 1,000 (1900) to 884 per 1,000 (1930). See A. van Marle, "De groep der Europeanen," Indonesië 5, 4 (1952): 320-21. In 1905 4,000 European women, born in Europe, were counted in Java; in 1930 26,000.
} 
In order to analyze the female discourse on domestics within its (numerical) proportions and within the framework of the male colonial discourse on the colonized other, we first need to cast a glance at this broader context of male Dutch representations of Indonesian society. Second we need some factual information on domestic service in the Indonesian Archipelago at that time.

\section{"Different" or "One Step Behind"?}

In the male political discourse on Indonesian society and Indonesians, we can identify two distinct modes of thought. ${ }^{11}$ In line with evolutionary theory of nineteenth to early twentieth-century anthropology, representations by Dutch progressives depicted Indonesians as similar to themselves, but less developed, still one step (or more) behind in the track of time. Indonesians, like children, would in due course catch up and be associated with the Dutch. These colonialists considered it their task to further this developmental process. Evolution theory was reflected in a moderately progressive colonial policy, the so-called Ethical Policy, which started around 1900. It was voiced in a rhetoric of the family-Indonesian children under tutelage of the West-with strong paternalistic overtones. Indonesians were part of the family of man but the younger generation. ${ }^{12}$

This rhetorical practice was not a new invention of those twentieth-century progressives, but was rooted in a long administrative tradition. In the Dutch East Indies the governor-general held the honorary title of "father" to the indigenous rulers and royalties, while indigenous civil servants addressed Dutch civil servants as "older brothers." Family titles were subtle and euphemistic expressions of strict hierarchy and power relations, asking for compliance and consensus, as in contemporary Indonesia they still do. ${ }^{13}$ Thus the familial rhetoric itself had a double-edged and ambiguous connotation, on the one hand one of familial solidarity and harmony, and on the other hand one that conveyed hierarchy and subtle power. This tallied with general conceptions of the family as a social institution with clear patterns of authority of the time under consideration.

In contrast with this familial rhetoric-and sometimes also in a paradoxical combination with it-more conservative Dutchmen in the colonies viewed Indonesians as fundamentally and innately different; different in race, cultural outlook, and behavior. This "Orientalization" or "Orientalism" implied a racism, although this was rarely expressed in biological terms. It represented a permanent conservative trend in Dutch colonialism, exacerbated by an ever-present and deep-seated fear; apprehension of both the unknown and strange, whether guna-guna (witchcraft), amok (sudden explosions of rage), unknown customs, or Indonesian nationalism; fear also of the loss of the colony, ending personal position and diminishing Dutch political identity. What would Holland, a dwarf on the international scene, be without its giant possession, the Indonesian Archipelago? a farm by the North

\footnotetext{
${ }^{11}$ Elsbeth Locher Scholten, "Female Labour in Twentieth-Century Java; European Notions-Indonesian Practice," in Indonesian Women in Focus. Past and Present Notions, ed. Elsbeth Locher-Scholten and Anke Niehof (Leiden: KITLV-Press, 1992), pp. 77-79.

${ }^{12}$ Frances Gouda, "The Gendered Rhetoric of Colonialism and Anti-Colonialism in Twentieth-Century Indonesia," Indonesia 55 (April 1993).

${ }^{13}$ See, on Ibuism (motherhood of the state) Madelon Dajadiningrat-Nieuwenhuis, "Ibuism and Priyaization: Path to Power?" in Locher-Scholten/Niehof, Indonesian Women, pp. 43-52; on "Bapakism": Julia Suryakusuma, "PKK: The Formalization of the Informal Power of Women" (Paper, 3rd International KITLV Workshop, Leiden 1988).
} 
Sea. ${ }^{14}$ This existential and political vulnerability implied fearful visions of the future, repressed and therefore rarely taken into account before World War II, but always just below the surface.

It appears most probable that colonial domestic servants were represented more as the "other" than as "one step behind" on the evolutionary ladder. The latter position was generally reserved for the Javanese elite, who could catch up by absorbing Western education. Different in race and class (and gender), servants illustrated the "otherness" of the colonized subject in its most poignant clarity. On the other hand, we have to take into account that these servants were domestic servants. Intimately connected to the family, they formed part and parcel of a paternalistic system. The view of domestic servants as part of the family, rather than as laborers, had a long tradition in Europe. ${ }^{15}$ Hence, either "Orientalism" or the rhetorical celebration of the family/"familization" or both may have determined colonial views on domestic servants. But before elaborating upon those themes, we first need to know some facts and figures concerning servants in the prewar Dutch East Indies.

\section{Facts and Figures on Colonial Domestics}

Domestic service had a long tradition in Java as well as in other parts of the Archipelago, and it appeared in many different forms. According to their status and wealth, members of the indigenous elite employed servants in smaller or larger numbers. Domestic servants could be common villagers who might be servants because of debt bondage or corvée obligations. But impoverished relatives could also join the households of their more prosperous family members and serve them. In a socially layered society like the Javanese, relationships between employers and servants were always hierarchical. They might resemble patronclient bonds and contain all the elements of distance, power, and fear but they could also be of an emotionally warm and familiar nature. ${ }^{16}$

Dutch colonialists, placing themselves above the Javanese aristocracy, accommodated to the social patterns of Javanese society. Eurasian women, married to and heading the households of Dutch immigrants, had played a major role in these processes of acculturation since the seventeenth century. ${ }^{17}$ Dutch men had accepted this pattern of domestic service the more easily, since the climate as well as colonial prestige in their opinion demanded a leisurely pace of life. Relations between Eurasian men/women and their Javanese servants might still remain warm and familiar, especially those between women, the nyonya and her

14 H.L. Wesseling, Indië verloren, rampspoed geboren en andere opstellen over de geschiedenis van de Europese expansie (Amsterdam: Bert Bakker, 1988) p. 288.

15 This view can be found already in fourteenth-century Florence. See Christiane Klapisch-Zuber, "Women Servants in Florence during the Fourteenth and Fifteenth Centuries" in Women and Work in Preindustrial Europe, ed. B.A. Hanawalt (Bloomington: Indiana University Press, 1986), pp. 56-80. See also Dudden, Serving Women, where the development from household member to domestic servant in nineteenth-century America is described. According to nineteenth-century law in Europe, domestic servants had the status of children, "protected by and subject to the authority of the parent employer" (McBride, Domestic Revolution, p. 15). In the Netherlands in 1906 a servant was not considered a wage earner, but "a household member" (hence not in need of social legislation; Henkes and Oosterhof, Kaatje, p. 59).

${ }^{16}$ See, for the many forms of Indonesian servants, the descriptions in the book for girls written by the Javanese Arti Poerbani (ps. A. P. Djajadiningrat), Widijawati, het Javaansche meisje (Amsterdam: Keizerskroon, 1948).

17 Jean Gelman Taylor, The Social World of Batavia: European and Eurasian in Dutch Asia (Madison: University of Wisconsin Press, 1983); Idem, "Women as Mediators in VOC Batavia," in Women and Mediation in Indonesia, ed. S. van Bemmelen et. al. (Leiden: KITLV Press, 1992), pp. 249-64. 
$b a b u$, as seen in Dutch colonial fiction from the Indies. ${ }^{18}$ In the twentieth century a different attitude was prescribed by and for totok and a growing number of Indies women, as we will see below.

Domestic servants were thus considered indispensable to Dutch colonial society. It was the married woman, either totok or Indisch/Eurasian, who was responsible for these servants in the first place. Often, the only Indonesians colonial women met in daily life were the servants. ${ }^{19}$ At the beginning of the twentieth century a European household required, as a minimum, a houseboy (jongos or sepen), a housemaid or nursemaid (babu), and a boy for the horses and the garden (kebon). ${ }^{20}$ The most popular household manual of 1913 reckoned that seven servants were needed: in addition to the jongos, the cook (kokki), the babu, and the kebon, someone was required for the sewing (jait) and washing, as well as a coachman and/ or a driver. ${ }^{21}$ Another manual recommended ten. ${ }^{22}$ Between four and six servants was the generally accepted number among Dutch colonialists in the twentieth century. Rich people could have more, poorer ones might have less, even only one servant. In the cities, where tap water, gas, and electricity were gradually introduced after 1900, the number of servants would decline. New city planning and construction involved smaller houses with modern sanitation, providing less room for servants who traditionally used to live in the backquarters of their employer's house, often with their families around. In this new situation servants might come in only during the day and live in the kampung. ${ }^{23}$ But whether servants stayed on the grounds of the house or in the kampung, domestic service remained an essential feature of colonial culture. Even when in dire need (such as during the economic crisis of the 1930s) Dutch colonial families would adhere to this ostentatious privilege of power. ${ }^{24}$

Only a small number of Indonesian/Javanese were, in fact, servants: in 1930 a mere 2 percent of the total Indonesian working population were classified as domestics, i.e. 350,000 persons ( 300,000 in Java, 50,000 in the Outer Regions). The actual number of Indonesians engaged (and registered) as domestic servants in 1930 seems to have been closely related to the presence of Europeans, rich Chinese, and the indigenous courts. Where these were concentrated, the largest numbers of servants could be found (Java, Sumatra's East Coast). ${ }^{25}$ Domestic service formed part of a stratified, elitist society, characterized by an abundant supply of labor.

The numbers and composition of this section of the labor force illustrate the pre-industrial character of Javanese society in those years. Contrary to the situation in Europe, where a feminization of household service had accompanied the Industrial Revolution and where

18 See, for instance, E. Breton de Nijs, Vergeelde portretten. Uit een Indisch familiealbum (Amsterdam: Querido, 1973).

19 See the quote on page 37 of this article.

${ }^{20}$ As the young wife of a young civil servant learned from her older colleague. See Madelon Székely-Lulofs, Onze bedienden in Indië (Deventer: Van Hoeve, z.d.) p. 10. See also B. van Helsdingen-Schoevers, De Europeesche vrouw in Indië (Baarn: Hollandia, 1914), p. 32.

21 J. Kloppenburg-Versteegh, Het leven van de Europeesche vrouw in Indië (Deventer: Dixon, 1913).

22 C. J. Pekelharing, Waaraan moet ik denken? Wat moet ik doen? Wenken aan het Hollandsche meisje dat als huisvrouw naar Indië gaat (2nd printing. Gorkum: Noorduyn, 1927), pp. 46-47.

23 Ibid., pp. 44-45. Personal communication of Ms. L. Blumenthal, June 6, 1993.

24 Ems 1. H. van Soest, De Hollandsche vrouw in Indië (Deventer: Van Hoeve, s.a.), p. 96.

25 Deduced from Volkstelling 1930. VIII, pp. 126-27. In Java and on Sumatra's East Coast, 2 percent or slightly more of the working population was in domestic service. In Bangka it was as high as 2.8 percent. Elsewhere the number was below one percent. 
domestic service had become the main occupation for women, ${ }^{26}$ domestic servants in colonial Indonesia were not exclusively or mainly female. ${ }^{27}$ Of the indigenous servants in Java and Madura 39 percent were male, and 61 percent female in 1930, the majority of the latter being unmarried women ( 72 percent). ${ }^{28}$ Only 4 percent of the total female labor force worked in households, while only one percent of all working men were in domestic service. ${ }^{29}$ Neither was it the major field providing Indonesian women with work, as it was in Europe. For Indonesian women it remained one of the less "popular" activities. Indigenous agriculture (employing nearly 40 percent of all working women), (small-)industry (nearly 25 percent), and (small-)trade (12 percent) prevailed over household labor. ${ }^{30}$

As far as the position of family servants within the household was concerned, vague outlines of a hierarchy among them can be discerned. Most often, the jongos or s(e)pen would come first; in other cases, a trusted and experienced older babu..$^{31}$ The jongos had the task of preparing breakfast, dusting and cleaning the galleries of the house, and serving food at meals or during social gatherings. Although he performed tasks which in European eyes might belong to the domain of women, he resided in the "outer world" of display and representation, the galleries, the receiving of guests, in Javanese tradition the male part of the house. Second in importance might be the (always female) cook, for a kokki who could "prepare a nice rice table and serve a reasonable European dish," was considered "of inestimable value and and incalculable dignity." 32 The (female) babu's task was to dust and clean the sleeping rooms and to care for the children, while the kebon (gardener), always male, worked outside and fetched water if necessary. Sewing and washing were not restricted to one gender; they belonged to the more flexible tasks open to either men or women. The division of labor among servants according to gender seems to have been rather fluid. It tallied with hierarchies of age and with the fluid gender systems and subtle gender boundaries that characterized Javanese social structure. ${ }^{33}$ Moreover, it concurred

${ }^{26}$ McBride, Domestic Revolution, pp. 82-99. In Europe the dramatic growth of this institution had gone hand in hand with the processes of industrialization and urbanization and had reflected the burgeoning growth of a middle class. Newly middle-class "arrivistes" asserted their new status through the employment of domestics, while domestic service offered women the possibility of upward mobility. Domestic service remained the major occupation of women until 1940 in the United States, England, and France; McBride, Domestic Revolution, p. 111. In the Netherlands, domestic service accounted for 44.4 percent in 1899, and 31 percent in 1930 of the female labor force. Industry and agriculture came second (17 percent and 19 percent in 1899 and 19 percent and 15 percent in 1930). Henkes and Oosterhof, Kaatje, p. 14. In Germany domestic service came second after agriculture, employing 20 percent of the female labor force; Ottmüller, Dienstbotenfrage, p. 15.

27 Volkstelling 1930. VIII. Overzicht voor Nederlandsch-Indï̈ (Batavia: Landsdrukkerij, 1936), pp. 126-27. Seven hundred servants belonged to the European population group, housekeepers replacing an absent mother, or nurses for children. Just 0.5 percent of the servants were of Chinese descent. Here only the Indonesian group will concern us, since the others figure rarely in the nonstatistical sources.

${ }^{28}$ Deduced from Volkstelling 1930. III. Uitkomsten voor Oost-Java (Batavia, Landsdrukkerij, 1934), pp. 94-95. Of the male servants most were married ( 57 percent).

29 Ibid.

30 Deduced from Volkstelling 1930. III, pp. 94-95.

${ }^{31}$ For the first, see Kloppenburgh Versteegh, Leven and D. C. M. Bauduin, Het Indische leven (The Hague: Leopold, 1927); on the second, Székely-Lulofs, Bedienden, p. 20. According to the latter the babu received a monthly salary of $f 25$.-, while the jongos and kebon received $f 9 .-$ and $f 7 .-$.

32 Bauduin, Indische leven, p. 67.

33 Shelly Errington, "Recasting Sex, Gender and Power: A Theoretical and Regional Overview," in Power and Difference. Gender in Island Southeast Asia, ed. Jane M. Atkinson and Shelly Errington (Stanford: Stanford University Press, 1990), p. 5; Shelley Errington's remark is useful in this respect: "In island Southeast Asia, by contrast 
with traditional lines of spatial organization in the Javanese household, the outer world being reserved for men, whereas the inner space and the back of the house were the domain of women. ${ }^{34}$

Recruitment of servants took place mainly by word of mouth, either on the recommendation of trustworthy servants or through the intercession of European friends. In Batavia in the 1930s some professional Bedienden-kantoren (offices for servants) mediated between employers and servants. The Association of Housewives in the Indies, founded in 1931 in the wake of a late professionalization of female activities in the Indies, ${ }^{35}$ did the same. It provided its members with bediendenpassen (evaluations, or letters of recommendation, which employers completed after one year of service); it published advertisements and organized contact-addresses. ${ }^{36}$ For others the indigenous kabar angin (rumor, literally: the sound of the wind) did its work: some families found their personnel waiting for them when returning from a European leave. From these data we may deduce that a more or less clearly defined "professional" identity existed among servants. One was a servant, a babu, a kokki.

Indigenous domestics were trained on the spot. They learned the work from their nyonya or from other servants. The issue of simple basic education in housekeeping skills for desa girls emerged as a point of discussion only in the second half of the 1930s. There are no indications that it got off the ground. ${ }^{37}$ In the 1930s the Association of Housewives in the Indies organized some short-term courses in cooking (European menu) for Indonesian kokki as well as courses in sewing for babu..$^{38}$ In the 1920s and 1930s some secondary schooling (two years) was available after primary education to prepare girls of all population groups for household activities (the so called nijverheidsonderwijs voor meisjes). A specialized school

[to the US], speculations about the reasons of differences between people [. . .] seldom put anatomy or physiology at the center." Ibid., p. 57. See also Ward Keeler, "Speaking of Gender in Java," in ibid., pp. 127-53.

34 Although researchers on the household in Indonesia accept this as a general pattern, no specific studies on the spatial organization of the Central Javanese household seem to be available. For Madura, see Anke Niehof, "Women and Fertility in Madura, Indonesia." (PhD thesis, University of Leiden, 1985), pp. 215-16. On West Java, see R. Wessing, Cosmology and Social Behavior in a West Javanese Settlement (Athens, Ohio: Ohio University Center for International Relations, Southeast Asian Program, 1978), pp. 53-63.

35 This association started twenty years later than its Dutch sister association. Its establishment was strongly influenced by the crisis and a growing need for organization: housewives had to cope with fewer servants and less money. (De Huisvrouw in Indië 1, 10 [August 1932]: 5.) As for the urge to organize female activities in a professional framework: the Dutch East-Indies Society for Philanthropic and Social Work had been launched a year earlier; in 1931 Indo-European women organized themselves into a separate branch of the political IndoEuropean Association; in that year also a school for home economics was founded, followed in 1933 by a school for social work. The purpose of the association was to create a platform for housewives and to enhance the status and practice of housekeeping. In its monthly journal, De Huisvrouw in Indï̈, attention was given to such activities as cooking and sewing, gardening, pet animals, children, etc. The association was explicitly open to members of all population groups. Indonesian priyayi (Javanese elite) ladies took part in it, but the atmosphere of its journal remained thoroughly European as well as apolitical. This character was even more strongly present in the De Huisvrouw in Deli, the monthly paper of the East Coast of Sumatra branch of the association. See De Huisvrouzw in Deli, passim.

The association counted more than 10,000 members just before the war and was an important source of information on practical aspects of housekeeping in the Indies.

${ }^{36}$ On "Bediendenkantoren," see De Huisorouw in Indië 7, 2 (1938): 72.

37 A. J. Resink-Wilkens, "Huishoudonderwijs voor het dessa-meisje," in Indisch Vrouwenjaarboek 1936, ed.

M. A. E. van Lith-van Schreven and J. H. Hooykaas-van Leeuwen Boomkamp (Jogjakarta: Kolff-Buning, 1936), pp. 61-67.

${ }^{38}$ Huisvrouw in Indië 5, 2 (1936): 83; 5,7 (1938): 643. 
for home economics for girls was founded only in 1931, but because of its requirements of a high school certificate it was beyond the reach of Indonesian personnel.

About the salaries and fringe benefits servants received we remain in the dark. The Association of Housewives in the Indies produced lists of usual wages, but did not publish them. Days of leave were not common for indigenous personnel; just before the war such days off were officially recommended for European personnel but not for Indonesians. ${ }^{39}$

In the 1920s and 1930s some changes took place in the position of servants, because of the totokization of colonial culture, mentioned above. The demand for higher standards for the (indigenous) personnel was translated into practical guidelines and stimuli such as medals for faithful service and a (very limited) number of courses in domestic work offered by the Association of Housewives in the Indies. The economic crisis of the 1930s, on the one hand, restricted the number of servants in individual households (a way of cutting the budget); on the other hand it pushed new groups into the labor market, amongst others Eurasian girls, trained in nijverheidsscholen. These changes, however, were barely reflected in Dutch representations of Indonesian servants in domestic manuals and children's fiction.

\section{Manuals and Advice Literature}

Dual messages characterize the manuals and instruction booklets for travelers and newcomers. ${ }^{40}$ Prescribed spatial arrangements, in the first place, marked otherness. Servants lived on the grounds in the servants' quarters at the back of the house, where the kitchen, the washroom, and the provision room were situated, in short where the physical functions of colonial superiors were cared for. Servants did not come into the house of their masters except to do their work. The nyonya was not expected to come to the servants' quarters either, except in case of illness or internal conflicts between servants. The liberty and autonomy of the latter required this distance, as one author maintained. ${ }^{41}$

Spatial and social separation was considered necessary not only in terms of physical contact but also as far as other bodily aspects were concerned. According to these manuals, a cordon sanitaire should be constructed socially around each home, ${ }^{42}$ as well as individually within each home. Children should not be allowed to eat the food the servants gave them. Mothers should feed the children themselves. Children should be forbidden to have conversations with the Indonesian servants. As teenagers they should be kept away from the ser-

\footnotetext{
${ }^{39}$ In 1914 four servants, working in one family, earned together $f 60$.- (Van Helsdingen Schoevers, Hollandsche vrouw, p. 32). Figures were only published in the 1930s: De Huisorouw in Deli 1, 8 (1931). The car driver received the best remuneration. In the 1930s the Association of Housewives in the Indies provided medals in silver and gold for long service. Of these 500 were distributed between 1936 and 1939, some to servants who had been more than forty years with one family (Huisvrouw in Indië 5, 10 (1936): 700; 6, 10 (1937): 593; 7, 10 (1938): 518; 8, 11 (1939): 618.

${ }^{40}$ The most widely used is the work of J. Kloppenburgh-Versteegh, Het leven van de Europeesche vrouw in Indie (Deventer: Dixon, 1913). Eurasian herself and raised in the Indies, the author was mother of a dozen children. See also Van Helsdingen-Schoevers (also a Eurasian), De Europeesche vrouw; Idem, Indië en Europa. Causeriën en beschouwingen over het leven in Ned. Indië over de vrouw en het kind en hun belangrijke problemen (Leiden: Leidsche uitgeversmij., 1929). Totok women giving information to others after 1920 were Rutten-Pekelharing, Waaraan moet ik denken?; C. Swaan-Koopman, Vrouwen in Indië (Amsterdam, 1932); M. Székely-Lulofs, Onze bedienden in Indië (Deventer: Van Hoeve, 1941). A man's voice can be found in D. C. M. Bauduin, Het Indische leven (The Hague: Leopold, 1927); S. Franke, "Indonesisch personeel," in Zóó leven wij in Indië, ed. C. W. Wormser (Deventer: Van Hoeve, 1943), pp. 241-53.

41 Székely-Lulofs, Bedienden, p. 22; see also Franke, "Personeel," p. 246.

42 As Ann Stoler has proven, Stoler, "Making Empire Respectable," p. 64.
} 
vants' quarters, because there they would learn facts about sexuality, considered improper and precocious by the puritanical standards of twentieth-century Western moral codes. In the 1930s a medical doctor cautioned mothers against surrendering their children to the care of the $b a b u$, since her unclean hands might infect small girls with venereal disease. ${ }^{43}$

Strict rules reigned in the field of hygiene. The babu should never wash the clothes of her master and mistress together with her own textiles, "a serious offense against tradition." 44 If she did so, she could be fired immediately. Neither should she wash those clothes at the well near the servants' quarters; her master's bathroom was the proper place. The two worlds should not touch each other that intimately, as the same author informs us. Fear of the other was expressed in terms of cleanliness and hygiene. The white body itself was considered beyond the reach of the other race. This message was voiced both explicitly and implicitly. ${ }^{45}$ These modern manuals preached lessons, that deviated from ninteenth-century and early twentieth-century practice of race relations within the majority of the (Eurasian) households where babu massaged their nyonya and were in close relationship with them. Moreoever, this distancing conveyed a clear message in a paradoxical situation. For it was servants, who by preparing food and serving it, by washing and cleaning, by looking after children, and by living near the bathroom, etc., were physically the most proximate of all Indonesians the colonizers met. If we take the messages of the manuals seriously, this nearness must have been scarcely bearable according to twentieth-century white opinion.

Stories about servants were indeed highly ambivalent. On the one hand, Indonesian servants were depicted as dirty, lazy, and unreliable; on the other, they were praised for their inner culture, skills, compliance, and modesty, for being easier to find and easier to get along with than servants in Europe. On the one hand, babu were condemned for spoiling European children, since they created little potentates by fulfilling all their wishes: the Indonesian custom of not allowing any crying conflicted in a direct way with European pedagogical notions about the productive role of frustration in "building" a child's character. ${ }^{46}$ On the other hand they were praised for their loyalty and devotion:

The devotion of a babu towards a child she is caring for is touching. True, one has to keep an eye upon her to prevent wrong habits; nevertheless I think that the devotion of the babu is infinitely greater than that of a Dutch nursemaid. She attaches herself wholeheartedly to your child and keeps this attachment her whole life. ${ }^{47}$

\footnotetext{
43 P. Peverelli, "De hygiëne van het gezin" in Indisch Vrouwenjaarboek, ed. Van Lith-van Schreven and Hooykaasvan Leeuwen Boomkamp, pp. 100-104; also Ibid., p. 149; Székely-Lulofs, Bedienden, p. 55. The puritanical standards of the Indies community can be derived from a review of the first book in Huisvrouw In Indië, which stated that the drawings of the female parts of the body made the book inappropriate for the common room in the home; Huisvrouw in Indië 5, 2 (1936): 115. See also Kloppenburg-Versteegh, Leven, p. 67; Bauduin, Indische leven, p. 59; Van Soest, De Hollandsche vrouw, p. 28.

44 Székely-Lulofs, Bedienden, p. 42.

45 I could find no references to the washing habits of domestics in Javanese culture and in Dutch homes in the Netherlands. Hence, I cannot relate them to a broader pattern of either Javanese or Dutch culture. Here they certainly confirm the preaching of distance in all physical aspects.

$46 \mathrm{Kloppenburg-Versteegh}$ again was the most expressive in this respect. Babu would have very special means to silence a child and get it to sleep: not only rocking but even opium, "rubbed in on parts of the body decency prohibits being called by name." (Leven, pp. 64-65). For a more balanced opinion, see Indisch Vrouwenjaarboek, pp. 44, 230.

${ }^{47}$ T. Brondgeest Sr., Nederlanders in Indï̈ (Baarn: Hollandia, 1919), p. 39. For a description of the faithfulness of male servants see also G. Jonckbloet, "Over Inlandsche bedienden," Studiën, Tijdschrift voor Godsdienst, Wetenschap en Letteren (1917): 269-94 and C. J. Jongejans-van Ophuijsen, "De B. B.-vrouw in de Buitengewesten" in
} 
Virtually all authors underlined the difference in habits (adat), in language, and in emotions between colonial employers and indigenous servants. However, they did so in diverse ways and tones. Servants might be vilified or their actions might be described in more understanding terms. For instance, their different opinions regarding personal property were condemned outright or "explained," by calling theft a sport, i.e. taking what was left over/behind. ${ }^{48}$ Their habit of asking for a perskot (advance money, in Dutch: voorschot) was smiled upon or indignantly rejected.

J. Kloppenburgh-Versteegh, one of the most important spokeswomen on the subject and Eurasian herself, held her Indonesian servants in very low esteem indeed. Of all authors, she demonstrated racism in the most explicit way: "in everything you will see that Javanese servants are no European personnel but only machines." ${ }^{49}$ Repeatedly, she typified them as filthy, lazy, and unreliable. But she also ended her book with the-then common-"ethical" rhetoric of the family: "Our servants are like big children. Let us try to understand their situation and feel compassion for them, this will urge us to improve their lot, to uplift them." 50 European (both totok and Indies) women should educate their servants, teach them hygiene, and improve their standard of life. This metaphor of the child, one of the most common for servants, implied a motherly attitude on the part of the mistress. ${ }^{51}$

These images of the other, of servants, mirrored images of self. European women themselves should be clean and active. They should control their servants, teach them hygiene, and be very careful when receiving them into their household. Order and regularity should reign supreme in the home. "We Europeans are obliged to set the example in everything, even if it gives us trouble and displeasure." 52 One of the means of doing so was to learn Malay, the lingua franca of the Indonesian Archipelago as soon as possible-this would enhance their prestige among the servants-and another was to get to know native habits. Moreover, women should react in a wise and restrained manner. Only then would they be able to control and supervise their servants. ${ }^{53}$ Behavior toward the servants should be calm, self-possessed, never angry, but always resolute and superior.

In all behavior, in word and deed, one should remain the calm superior, the higher placed person, to whom the servants will look up. (. . .) Hot temper is always harmful, especially to the mistress, who by her excitement does not manage to control her sentences. ${ }^{54}$

Or as Kloppenburg-Versteegh put it:

Remember not to speak to the servants when in anger: in the first place you will not impress them; in the second place you will upset yourself, while the servant might ridicule your words. ... 55

Indisch Vrouwenjaarboek, ed. Van Lith-van Schreven and Hooykaas-van Leeuwen Boomkam, p. 44; Franke, "Indonesisch personeel," p. 247.

48 Székely-Lulofs, Onze bedienden, pp. 35-36.

${ }^{49}$ Kloppenburg-Versteegh, Leven, p. 54.

50 Ibid., p. 112.

51 Rutten-Pekelharing, Waaraan moet ik denken?, pp. 50-51.

52 Ibid., pp. 3-4.

53 See also Van Helsdingen-Schoevers, De Europeesche vrouw, p. 25 and Van Soest, De Hollandsche vrouw, p. 111.

${ }^{54}$ Catenius-van der Meiden, Ons huis, p. 141.

${ }^{55}$ Kloppenburg-Versteegh, Leven, p. 53. Also Van Helsdingen-Schoevers, De Europeesche vrouw, p. 32. 
One should not express "complaints" in the form of harsh scolding: "natives hate rows and abusive language." 56

This "emotionology" (ideologically permitted emotions) coincided with Javanse ideals about halus (restrained) behavior. Moreover, it reflected the cultural ideals of the white colonial upper class of that period, which exacted the same attitude from women toward their husbands and children. ${ }^{57}$ For white women, anger was the least appropriate of all emotions, since it would lower white prestige.

And to maintain and bolster prestige was one of the most important tasks of colonial women. It was after all the main reason to have servants. As a male writer concluded: "In the first place a decent European [man/woman] does not perform manual work or home work because of his prestige, and in the second place it is far too hot to do so." 58 Prestige was the reason behind proper and restrained behavior, behind learning the servant's language and being informed about his or her culture. Like men in the world outside, women should maintain white prestige within the domestic sphere.

Of course there may have been (and were) Dutch and Eurasian women in the Indies who wanted to know more about the society and people among whom they were living. But this was not the first message of the Colonial School for Girls and Women in The Hague, founded in 1920, whose program was informed by the same ambivalent attitudes of "Orientalism" and "familization." Succeeding earlier short courses on hygiene for women going abroad, the school was firmly rooted in a pragmatic approach: the growing need for hygiene and medicalization as well as the professionalization of the domestic scene. Both "movements" were exported to the tropics. Between 1921 and 1938 approximately 1,000 women followed the three-month courses in tropical hygiene, tropical medicine, food, ethnology, and Malay, offered by the school. ${ }^{59}$

Behavior toward servants formed part of the lessons on home economics. On the one hand, the school provided its pupils with the negative images of Kloppenburg-Versteegh, whose 1913 book was the main textbook on domestic servants. On the other hand, the school depicted Indonesians, painted so often "unnecessarily black," as completely different people, but "not less" than the Dutch. 60 Although servants did not figure prominently in the curriculum, the school's success was attributed to its efforts to increase the knowledge of the language and of the habits of the servants among its students. It achieved its goal of preventing unnecessary fear of the strange surroundings, "of natives, wild beasts and ser-

\footnotetext{
56 Rutten-Pekelharing, Waaraan moet ik denken?, p. 50.

57 Carol Z. Stearns and Peter N. Stearns, ed., Emotion and Social Change. Towards a New Psychohistory (New YorkLondon: Holmes and Meier, 1988), p. 7. See also Kloppenburg-Versteegh, Leven, pp. 90, 91 , 98 on behavior toward children. The same conduct is prescribed in children's fiction. Girls should not be choleric or hottempered (G. C. van der Horst-van Doorn, Kitty's lief en leed. Van Indisch meisjesleven (Gouda: Van Goor, 1923). Practice might be different. In 1936 it was noted that children should speak to servants in a friendly way, not scolding them "as one hears so often"; parents should set the example. Van Lith-van Schreven, "Zullen wij onze kinderen naar Holland zenden?" in Indisch Vrouwenjaarboek, p. 231.

58 Bauduin, Indische leven, p. 65.

59 Archive Koloniale School voor Meisjes en Vrouwen [Colonial School for Girls and Women], file 77, 78 and 86. Algemeen Rijksarchief (General State Archives), The Hague.

60 Brochure 1923, Archive Koloniale School, file 77; Radiorede Ros Vrijman, 19-7-1938, Archive Koloniale School, file 81 .
} 
pents [sic]."61 As former pupils reported, servants were "no absolute strangers," once these pupils arrived in the Indies. ${ }^{62}$ The fear of the unknown had gone.

The idea of the necessary contact with the silent, dark population of their future country does not have anything oppressive any more, since they have learned to understand the language and the religion and know how to respect it. ${ }^{63}$

But the Colonial School wanted to do more. It wanted to prepare Dutch women for their "beautiful and educational" task in Indies society, to make them "pioneers" in medical care, surpassing the narrow enclave of their Indies' home. The image of self engendered in these Dutch women was one of active "mothering." Mothers in the Indies, especially those outside Java, were held responsible not only for their own family, but for lots of families, including those of their domestics, first and foremost in cases of illness. The school wanted to teach women "how they could be a helpmate and an adviser to them [their domestics] and for the natives in general in their surroundings." 64 The school should raise, as a firm believer of "ethical" ideas postulated,

a woman's consciousness of her future, her task, her calling, when she possesses the means to find the way to the soul of the people she is going to live with [...] when she feels that she also has a national task, i.e. to create bonds of appreciation and devotion between the people of the Netherlands and the people of Insulinde (the Indonesian Archipelago). 65

It was this larger framework of mothering that incorporated white women into the realm of colonial domination; it enlisted them in the ethical colonial project and diminished the boundaries between the home and (colonial/Indonesian) society at large. Servants were to European women the primary representatives of this society. The Colonial School's official ideology suggested that the task of white women was broader and nobler than being enclosed in the house. It might even convert the housewife's role into an attractive occupation, providing her with an honorable social purpose to live for. In this discourse we find again a familial rhetoric, in close but not unequivocal harmony with the otherness and Orientalization of domestic servants. This female discourse was completely in tune with the male dominated political discourse of the time under consideration.

Race, class, and gender, "the axes along which inequalities of power between men and women [and between colonizer and colonized] are organized and maintained,"66 each played their own (hidden) role in this discourse. Domestic servants were to a large extent desexualized. Little difference was made between male and female domestics. Servants were treated as a non-gendered group, in which only the babu might be granted a special place, since she, through her task and her (appreciated) devotion to the children, came closest to the family. This non-differentiation may have tallied with Javanese fluidity of sexual markers, as well as with a Victorian prudery of the authors who accustomed themselves to this Javanese position all the more easily. Neither were class differences between employer-employee taken into account; only incidentally does one find any remark on that

61 Radiorede Ros Vrijman, 19-7-1938, Archive Koloniale School, file 81.

62 Brochure 1923; Vierde propagandaboekje 1927, Archive Koloniale School, file 77; Radiorede Ros Vrijman, 197-1938, Archive Koloniale School, file 81.

63 Brochure 1923, 12 Archive Koloniale School, file 77.

64 Brochure 1923, 10, 12; Derde propagandaboekje 1925, 4, 16. Archive Koloniale School, file 77.

65 Brochure 1923, 9. Archive Koloniale School, file 77.

66 Joan W. Scott, "Gender, a Useful Category of Historical Analysis," American Historical Review 91 (1986): 1054. 
subject. ${ }^{67}$ The third marker of difference, race/otherness, figured most prominently in the discourse, voiced in terms of differences in culture and education.

In sum, we find dual messages in the European female manuals on domestics in the Indies: distance and nearness; unreliability and loyalty; Orientalization and familial rhetoric, reflecting the colonial discourse on Indonesians as part of the family of man to be educated/as the totally different.

This twofold discourse on servants betrayed the deeply ambivalent attitude of white Dutch women and men toward their Indonesian surroundings in general, and toward their Indonesian servants of a different race and culture in particular. Servants, male and female, were kept at a distance psychologically and ideologically, in glaring contrast to their daily proximity. It was this nearness, undeniable and unchangeable, as well as the experience of being dependent on Indonesian servants that, paradoxically, stimulated the ideology (and practice) of distance. Of all Indonesians, servants came nearest to Europeans. Mistress and servants were thus tied together in an ambivalent relationship; their lives were interwoven in a most intimate manner. ${ }^{68}$ This intimacy was one face of the Janus head of the employerservant relationship, in opposition to the second face, that of power, prestige, and superiority.

It is interesting to note that literature about Indonesian servants, published in the Netherlands during World War II, tended to stress the rhetoric of the family more strongly than before. In this period of national Dutch trauma and of a despised Nazi ideology, ex-colonialists apparently idealized the colonial relationship, glorifying a national colonial past as well as the harmonious living together of different races, within the home and beyond. ${ }^{69}$

In practice, being a white or Eurasian housewife in the Indies was to reign over the known (a house) and the unknown (servants). It meant arriving with Western ideas of superiority and power, of hygiene and education, and having to adapt oneself to tropical circumstances and Indonesian habits, unknown and frightening. This created the psychological tensions and the paradoxical attitudes of colonial employers, that Indonesian/Javanese servants had to endure.

\section{Children's Literature}

How were these dual messages translated into children's literature, if at all? What visions of the other did Dutch children in the Indies absorb? Whether or not literature may serve as a trustworthy source of information about the past is the subject of a lively debate among historians and social scientists. Without entering into a detailed discussion of these matters, we may say that children's literature offers a useful source for the study of mentalities of grown-ups. For children's literature, especially Dutch literature from the prewar

\footnotetext{
67 A journalist, Melis Stoke, reminded his readers that servants could rarely be identified with the indigenous population in general. Melis Stoke, Wat men in Indië moet doen en laten (The Hague: Leopold, 1939), p. 100. See also Kloppenburg-Versteegh, Leven 6.

68 Albert Memmi has stressed the intimacy of this relationship as a reason behind the violence of servants toward their masters. A. Memmi, Dominated Man. Notes towards a Portrait (Boston: Beacon Press, 1971 ), p. 178.

${ }^{69}$ Székely-Lulofs, Bedienden, passim; Franke, "Indonesisch personeel," p. 252: "we belong to them and they to us. Together we continue to build our beautiful archipelago. . . Our heart gropes for that of our brown brother." Székely-Lulofs, famous for her highly critical Indies novels Rubber and Coolie, voiced the same ambivalence regarding servants as did the other authors, only her text is more sympathetic and understanding. In her novels she tries to write from an Indonesian point of view; her main story teller is an old Javanese babu.
} 
period, was highly prescriptive, representing the ideas and ideals about (colonial) society, that the European middle-class considered valuable enough to pass on to the younger generation. This literature represented more how things should be, than how they were, more the "Sollen" than the "Sein." 70 Hence, children's literature can be used as an entry to adolescents' comprehensions of the nature of colonial society and its inhabitants. Like domestic manuals it can be studied for Dutch colonial norms and values concerning servants.

This source itself may need a general introduction, which is made possible by the recent bibliography in Dutch on this topic, edited by Dorothée Buur. ${ }^{71}$ The "Indies" children's fiction (i.e. Dutch books set either in the Indies or in the Netherlands but referring to experiences and characters from the Indies) was thoroughly colonial. The genre was dominated by the Netherlands as far as themes, characters, and economic context were concerned. Because of the restricted demand in the Indies, very few books indeed (only 4 percent of the books mentioned in Buur) were edited there; editors in the Netherlands dominated the Indies market.72 Writers were mainly Dutch totok, born in the Netherlands; no books for children, written in Dutch by Indonesians, were published in that period. ${ }^{73}$ In the 1930 s, books for Indonesian children in Malay or Javanese were virtually nonexistent, except for the editions of the government service, the Commission for Popular Reading Material (Commissie voor de Volkslectuur), which published wayang stories, Indonesian legends, and translations of European fairy tales and children's classics. ${ }^{74}$

The subject matter and themes of this literary genre were colonial as well. Dutch colonial history (the period of the East Indies Company, the Aceh war) figured prominently; contemporary politics (nationalism) were rarely included. Indonesian culture was present primarily in books about Indonesian legends and fairy tales; Indonesian children as central characters figured mainly in tales of missionaries and of some progressives. ${ }^{75}$ In books for girls, the position of central character was reserved for Dutch girls in the Indies or for Dutch girls from the Indies returning to or living in the Netherlands. Eurasian girls also appeared, but quantitatively they were on the sidelines. Here I will be dealing with books for girls, set in the prewar Indies, written mainly by totok women, because these focus on family life, and thus bring domestic servants into our range of vision. ${ }^{76}$

\footnotetext{
${ }^{70}$ L. Dasberg, Het kinderboek als opvoeder. Twee eeuwen pedagogische normen en waarden in het historische kinderboek in Nederland (Assen: Van Gorcum 1981); Bob Dixon, Catching Them Young. 1. Sex, Race and Class in Children's Fiction; 2. Political Ideas in Children's Fiction, vol. 1 (London: Pluto Press, 1978), p. 48.

${ }^{71}$ See Dorothée Buur, Indische jeugdliteratuur. Geannoteerde bibliografie van jeugdboeken over Nederlands-Indië en Indonesië (Leiden: KITLV-uitgeverij, 1992). From her 602 titles of the period 1900-1942 only a mere 26 were published in the Indies, many of them after the German occupation of the Netherlands in 1940 had cut all ties between the Netherlands and the Indies.

72 Ibid., p. 21.

73 Buur mentions only one book, of Arti Poerbani, Widijawati, written in Dutch and published in 1948 (see note 16).

74 See: J. H. Hooykaas-van Leeuwen Boomkamp, "Inheemsche kinderboeken," in Indisch Vrouwenjaarboek, ed. Van Lith-van Schreven and Hooykaas-van Leeuwen Boomkamp, pp. 189-94.

75 This Protestant mission played an important role in popularizing the Indies in Holland through children's fiction about Indonesian children, living their lives, having their adventures, and being adopted or rescued by the missionary in the end. Of books published from 1900 to 1942, 12 percent have the life of Indonesian children as a central topic, two thirds of those being inspired by the mission. Buur, Jeugdliteratuur.

76 Ibid., pp. 17-20.
} 
This literature for girls followed the general pattern of Dutch children's fiction of the period. The books were more ethical than aesthetic and conformed to the rigid moral codes of the prewar period. As a colonial government report stated in 1920:

If the effect is an awakening, reinforcing and comforting one, if the book has touched your conscience, if it has reconciled you to your work, your duties, your surroundings, to nature, to people ... then you have read a good book. ... A good book (. . ) arouses loving thought and noble deed; a bad book, (...) depresses one to doubt. ${ }^{77}$

Girls' books were ethical and "good" in that sense. They described reconciliation to difficulties as the resolution of all problems, either of a personal character (the hot-tempered girl developing into a mature woman, preferably a housewife) or of the family. The plot often presented a stereotyped narrative: the death of a mother (incidentally a father or a brother) as a crucial moment offering the possibility for change, adaptation, and (what we would call now) "personal growth." Presumably, death provided the story with emotional depth; it offered the heroine appropriate grief, and she could then exemplify the possibility of overcoming misfortune by reconciling herself to the situation. ${ }^{78}$

As might be expected from literature of the interwar period, these books represent highly traditional gender roles and gender relations. ${ }^{79}$ The (white) mother is depicted as being at home and the emotional center of the family. Cameraderie and friendship characterize relations between the parents. Girls have good relationships with them and treat their parents with respect or even friendship. Although some female protagonists yearn for a career, novels often end with "the most beautiful role for a woman, that of a wife and mother." 80

Race relations are ambivalent. Most books center on totok families. Open discrimination is frowned upon, but Indonesians are rarely its victims; in general it concerns the painful experiences of Eurasian children, scorned by whites. The view of Indonesian society is extremely limited. Java is present in lyrical descriptions of a beloved nature or of glorious holidays in the mountains. Race relations are restricted to relations with servants or with Javanese mothers. The Javanese mother, silent and withdrawn, is depicted as full of admiration for her mixed blood children; her children treat her with (some) respect but know they have to follow the white family when the white father has died. In Dona Alve ${ }^{81}$ the seventeen-year-old Eurasian girl of that name is not allowed to stay with her mother but moves to her rich uncle in Batavia. Here her all-white aunt has problems accepting her, although her younger white cousin grows very fond of her. A car accident (she is hit by her older cousin's car) changes her life; her aunt regrets her former discrimination. She and her husband allow Dona to become a singer in Europe. In the end, however, Dona leaves a promising career and returns to East Java, her maternal home, to become the wife of her childhood friend on

\footnotetext{
77 Een weg tot volksontwikkeling (Openbare bibliotheken en leeszalen). Uitgave van de Commissie voor de Volkslectuur (Batavia: Landsdrukkerij, n.d. [1920]).

78 Deceased parents figure in 16 percent of all youth books of the period 1900-1942, published in Buur, Jeugdliteratuur.

79 See Dasberg, Kinderboek, p. 182 on the traditional imagery in youth literature before 1940; J. C. H. Blom, "Een harmonisch gezin en individuele ontplooiing. Enkele beschouwingen over veranderende opvattingen over de vrouw in Nederland sinds de jaren dertig," Bijdragen en Mededelingen betreffende de Geschiedenis der Nederlanden 108 (1993): 28-50.

${ }^{80}$ Van der Horst-van Doorn, Kitty's leed en vreugde. Also, by the same author Tineke (Gouda; van Goor, n.d.).

81 M. C. van Zeggelen, Dona Alve (Amsterdam: Scheltema and Holkema, 1928).
} 
the coffee plantation. In another novel, Sinjo-Juul, ${ }^{82}$ a young Eurasian boy of that name is fetched by his Eurasian aunt-after the death of his father-to live in the city; he has to leave his Javanese mother who later comes to him. However, his mother has to remain in the servants' quarters of the house. Her in-laws do not allow her inside. Sinjo Juul manages in the end to find his identity and to accept his mixed roots. As an adult engineer, he returns to the Indies and vows that his mother will never live in the servants' quarters again.

\section{Servants in Youth Literature}

The representation of servants in this literary genre occurs within the context of the traditional, Europe-oriented family. Small wonder, then, that the rhetoric of the family prevails. In one of the most popular books, De Canneheuveltjes [The family Canneheuvel], written by Marie Ovink-Soer, wife of a former civil servant and one of the older Dutch women who were close to and inspired Kartini, servants are depicted as natural friends of the children. Baboe Tjidem takes them for walks to her mother in the desa, where the youngest dreams of later being a buffalo boy. Servants take part in the games at a birthday party. Having to leave them behind when the family returns to Holland is a painful experience, especially for the youngest, for Baboe Tjidem saved the child's life during the earthquake that killed his mother.

Race relationships in this popular book (published in 1912 and reprinted four times in the 1920s and 1930s) are harmonious. There is a fruitful cooperation between the second mother and the jait, who together prepare party costumes for the four children. When lost in the mountains during a wonderful holiday, an old Javanese desa woman receives and consoles the two lost children (in which language they communicate is not clear). The "evil" character is the Chinese, not the Indonesian. However, the novel clearly delineates the lines of authority. Succeeding some authoritarian European nurses and an indulgent Eurasian "aunt," the second (totok) mother finally brings order into the house: "She did not reign but guided and advised, did miracles with a soft, appropriately spoken word, both in the contact with family members and with servants." 83 Anger again is excluded.

The same mixture of familiarity and authority is repeated in many other books in this genre. The relationship of the Eurasian Dona Alve with the servants is even more natural and close, the babu being a kind of direct aunt. ${ }^{84}$ In Kitty's leed en vreugde [Kitty's sorrow and joy] the Dutch high-school student Kitty deplores the departure of the Ambonese girl/ housekeeper Nel who has quickly become an integral member of the family. Children of the Dutch family in Tussen sawah's en bergen [Between sawahs and mountains] are friendly with their servants, whom they found waiting for them in Bandung when they returned from their European leave. These servants organize a slametan (a ritual meal) for the new house, at which the father invites the children "to make this house a good one for everybody, also for the servants." 85 The servants help, admire, and care for pet animals together with the children. A motherless and difficult European boy, accepted in the family, offers the moral lesson of the story. This representation of harmonious race relations results in the ideal of one of the children (after a holiday at a tea plantation in the mountains) becoming a planter himself. The message is clear: the harmonious Indies as the home country for Europeans.

\footnotetext{
82 S. Franke, Sinjo-Juul (Amsterdam: Scheltens and Giltay, 1939). He is one of the important authors and one of the few male authors used here.

${ }^{83}$ M. C. E. Ovink-Soer, De Canneheuveltjes. Een verhaal uit het Indische kinderleven (Gouda: Van Goor, 1912), p. 76.

84 That this is not typical for all Indo-Europeans is shown by the aunt of Sinjo-Juul mentioned in the text.

${ }^{85}$ C. H. Sevenhuysen-Verhoeff, Tussen sawah's en bergen (Anersfoort: Valkhoff, 1936), p. 38.
} 
But there are other messages as well. In Een moeilijke jaar voor de Van Heerdentjes [A difficult year for the Van Heerden family] the widowed father admits that Holland has remained a source of yearning: "In spite of all those Indies years I have always had the strong feeling that we do not belong here." 86 In this novel we find more distance and superiority toward the servants. These servants may "love Nonna Elly, but native servants are just like small children: one has to keep a tight rein on them." 87 As prescribed in the manuals, but without reference to them, the oldest girl, who takes the deceased mother's place, washes and feeds the twin babies herself.

The adult accusation of babu, who spoil and over-indulge Dutch children, has its resonance in young people's literature, but only weakly in the books under review. In Aan den Oedjoeng [At the seashore], a fourteen-year-old girl, who recently lost her mother, remains alone with her father; a much beloved, affectionate, and faithful babu helps her ${ }^{88}$ Admiration for servants' loyalty is expressed most clearly in the (Christian-inspired) story, Wongso's offer [Wongsos' sacrifice]. ${ }^{89}$ This jongos leaves the European family without permission and uses his savings to fetch Chinese medicine in Singapore for the European girl Nonnie, paralyzed by a snake bite. He takes a plane (aviation is a recurring, literary theme in this genre in the 1930s) and after his return is fired for desertion. When, by accident, his story is revealed, the father of Nonnie restores him to his function. His Chinese medicine has not really helped, Western medical supplies are represented as clearly superior. But the girl recovers and old Wongso gets a pension (and a bible). In this book, the tone is not one of familiarity; the father admits he does not know "how to handle natives" when Wongso has asked permission to leave (using the popular excuse that a member of his family has died). But a profound respect for the sacrifice of a servant infuses this book's moral message; the father asks to be forgiven for his hot-tempered and premature reaction.

A last book, Ams houdt van Indië [Ams loves the Indies], published in 1941, seems to summarize many of the themes of manuals and youth literature, mentioned above. This book is highly informative on totok family life in Semarang and very Dutch in its focus on the cosiness and intimacy ("gezelligheid") of the family. 90 The fifteen-year-old high-school student Ams, the oldest of four children, was born in the Indies. Her father is in business. Servants are integral figures in the narrative. A natural and relaxed contact seems, at first glance, the primary message of this book.

But all earlier mentioned images of servants resurface. Should the youngest learn Malay from the servants? Is she not spoiled by the babu? In a long dialogue between Ams and her mother (a mother who in this book remains alive), the latter explains that she as a totok had been afraid that this might happen. For that reason she had decided not to have a babu when Ams was born. En passant, the mother admits her earlier racism: "Also I still had such an antipathy towards the Natives and the idea that one would touch your dear pink skin with its brown hands made me rebellious. What nonsense, Ams!"91 Then she continues her story. After a year, when she expected her second child, she got ill and had to ask for help. Two

\footnotetext{
86 Tine Ophof-Sterk, Een moeilijk jaar voor de Van Heerdentjes (Weltevreden/Amersfoort: Visser/Valkhoff, 1921), p. 198.

87 Ibid., p. 134.

88 A. Romein-Verschoor, Aan den Oedjoeng (Santpoort: Mees, 1928).

${ }^{89}$ M. van der Hilst, Wongso's offer. Een Indisch kinderverhaal (Hoorn: Edecea, 1937).

${ }^{90}$ M. J. van Marle-Hubregtse, Ams houdt van Indië (Deventer: Van Hoeve, 1941). It even presents a map of a colonial house.

${ }^{91}$ Ibid., p. 34.
} 
loyal servants, who are still with them, entered the house and put the household in order. "And ever since, Baboe and I have worked together." Gratitude to the servants is part of the dialogue between mother and daughter; and in the end the mother advises Ams: "You should not exaggerate the wrong influence of Baboe Roes. You will see, it will come all right later."

Relations with servants seem to be harmonious. However, if we look at the story with Toni Morrison's eyes we see other "black perspectives." 92 Turning points in the plot evolve around mistakes of servants or other Indonesians. Because the driver has not put the car's handbrake on, the toddler and Baboe Roes, playing in it, inadvertently cause the car to start moving. Had it not been for the resolute behavior of the second son who jumps on the car's running board and manages to reach the wheel, they would have crashed. When the mother is ill, servants become unruly. The kebon tries to break into the house, but Ams, warned by Baboe Roes, prevents the burglary. The servants are the ones who make the mistakes; heroism is a European attribute and is inscribed in Ams and her brother.

Orientalism is not absent. At difficult moments the father confesses: "they are such different people from us" or "They really are difficult people, those Natives" (when the driver, being ashamed of the near accident, asks permission to leave). ${ }^{93}$ Paternalism is also strongly present. Father provides the servants with their salaries, their perskot (advance); he teaches them how to save money. Both attitudes of Orientalism and paternalism are expressed at moments when Javanese behavior-its withdrawal, its silences-contrasts most strongly with Dutch directness and openness (or bluntness) and is not understood. The Javanese slametan (religious meal) for the happy ending of the car incident, however, is gladly attended.

Paternalism in a more hidden form can be discerned at the end of the story. When Ams and her brother Wim take a walk in the mountains during a long holiday, they find and rescue a Javanese boy who has fallen in the woods. They discover that he is Soedarso, a classmate of Ams. Soedarso realizes that he owes his life to her. Mother confesses after having met his uncle, a wedono (Javanese civil servant): "it is for the first time since I have been in the Indies [fifteen years or more!] that I meet such a Javanese. Except for our servants we are not in contact with Javanese families." 94

If we read the story as a metaphor, the messages may be clear: brown is where the danger lurks, whether in a runaway car or in a stealing servant; white may educate and even save lives, for which brown will be grateful.

Association-or harmonious coexistence-of both races is the final imagery of this novel. Together the children-Ams, Wim, and the recovered Soedarso-go for their last holiday walk. The following conversation develops:

"We have a very nice country indeed," Ams said with satisfaction.

"But this is not your country." Soedarso said calmly.

"This is not my country?" Ams said with indignation.

\footnotetext{
92 Toni Morrison, Playing in the Dark. Whiteness and the Literary Imagination (Cambridge, Mass. and London: Harvard University Press, 1992). In this study Morrison analyzes the concepts of black and white in white American literature from the starting-point that the dream is the dreamer. Hence, what it said about the object, tells us something about the subject/writer.

93 Van Marle-Hubregtse, Ams, pp. 45, 58.

94 Ibid.
} 
"Holland is your country," and Soedarso looked at Ams, a little shy about the effect of his words.

"Holland," said Ams, "Holland is the country of Mother and Father; they belong there. But not me, I belong here." In her excitement Ams got up and stretched out her arms. "I belong here," she repeated. "I was born here. I love these mountains and the people here!" Soedarso looked at Ams as she stood on the mountain top and he felt a deep sympathy for this blond girl from a different race that had accepted him so simply as a comrade and now also made his country her own.

These words are near the end of the story. They reflect the strong connection Indies-born children may have felt toward their country of birth, from which they-like other Dutchmen-could not distance themselves. The quote itself is thoroughly colonial. The idea of cultural (or political for that matter) association is expressed by appropriating the Javanese mountains, i.e. the Indonesian Archipelago, without asking the original inhabitants (Soedarso) for their opinion. Even stronger: the Dutch author inscribes on the Javanese boy tacit agreement with that act and love for the white girl who has saved his life and, as an exception to the colonial pattern, has approached him directly. Or as Soedarso "softly" says: "I did not know (. . ) you considered it that way." The rhetoric of the family implies an owning of country and people, not asking for and disregarding the opinions of Indonesians.

If we compare the views on servants in this children's fiction with those in the manuals, a few differences and more similarities come to the fore. Youth literature stresses harmony and family; its messages of difference are more implicit. Those of class are not elaborated upon; they are hidden under the ideology of the family in which everybody has his own (hierarchical) place. Differences in gender are not acknowledged. Women servants sometimes play a more prominent role, being closer to (or in) the house and to the family. But dedication toward children may be found in male and female servants, in Wongso and in Baboe Roes. Racism is rarely explicit, or described as only a past or transitory feeling. All differences (of class and race especially), however, are subtly present when we take these stories not only in a literal sense but also as metaphors. In that sense, as metaphors for the relations between the employer and indigenous servant, they are exemplary for the colonial relationship itself, in which Dutch supposedly educated and lifted the indigenous population to a higher level, and in which Indonesian opinion was rarely asked and Indonesians were seldom addressed directly.

\section{Conclusion}

The colonial imagination regarding servants in the prewar Indies consisted of two "ingredients": Orientalism or otherness as well as nearness or "familization." It reflected the male political discourse of the period, which incorporated both elements. Although colonialism as an adventurous European enterprise and as a practice of institutional dominance may have been primarily a man's affair, European women were not separated from it. The ideology of the colonial state as the family of men was derived from the home situation and was expressed in metaphors relating to the household. Tacitly, gender was included. Explicitly, European women occupied their place as colonial parents or guardians in charge of training servants, their first pupils. Servants became the metaphor for the colonial relationship, being both included in and excluded from the colonial family. Since the family at that moment of history was hierarchically structured, the ideology of the family gave colonial masters, whether male or female, a superior position and the right to rule, either in or outside the house. 
Were colonial women in the Indies more racist than men? It seems doubtful. The discourse on servants clearly harbored racist overtones in language and thinking. European women enacted ambivalent attitudes and formulated dual messages in the private sphere, culturally reserved to them at that period in history. Men, however, employed the same rhetoric in theirs, the political and industrial arena. Both Orientalization and "familization" were expressed, for instance, during the debate about the regulation of women's night labor in the all-male Volksraad (Indies proto-parliament) in 1925.95 Was female racism perhaps more painful because it was felt at home, in the informal setting of the family, where personal feelings were closer to the surface and abstract political structures could not conceal inhumanity? Even there, racism was not a female prerogative. In many novels, it was the father who expressed the "otherness" of the servants (for instance in Wongso's offer and Ams houdt van Indië).

Otherness and "familization" seem to be paradoxical opposites. Difference and nearness created complicated and paradoxical models of relationship. Manuals warned housewives of the first, literature educated girls about the second experience. But both sets of writings embodied elements of the opposite attitude. Orientalism and "familization" may even have been indissolubly related to each other, woven into a yin and yang entanglement. On the one hand, the nearness of indispensable servants and the average European family's dependence on them caused a psychological reaction of distancing, in terms of spatial design as well as symbolic categorization. On the other hand, this distancing could not go too far, for otherness would lead to a frightening unknown. Hence, otherness could only be mastered by making it, both literally and figuratively, familiar. And what was and is more familiar than the family? "Familization," in turn, could not be endured without some simultaneous distancing. In this ongoing paradox, Dutch colonials were caught. It illustrated the colonial relationship as such, which in the twentieth century moved between the opposites of distancing domination and familiarizing developing policies. Orientalism and "familist ideology" belonged to each other as opposite sides of the same (colonial) coin.

Of both attitudes, the rhetoric of the family might seem the more progressive; it had, however, its own faults. It masked many differences, especially those of race, class, and gender, the axes along which inequalities of power are usually structured (see above). It reduced servants to the status of children, who had to behave well, to do what they were told, i.e. to be "clean, honest, compliant, and capable." 96 This rhetoric had its own hierarchy and might be used in a progressive as well as in a conservative sense.

It is the quality of concealment or obscurity of this rhetoric, which made (and still makes) it politically useless, or even dangerous, for "subaltern" groups trying to delineate their (op)position. This criticism of familist ideology is not new. It has been expressed again in recent years with regard to Asian countries, such as the modern Indonesian state and the modern industrial organization of Japan. ${ }^{97}$ In the case of modern Indonesia, we may conclude that - even if the contemporary political rhetoric of the family did not have its roots in colonial "familization" - it was strongly reinforced by the ideology of Western colonialism.

\footnotetext{
${ }^{95}$ Locher-Scholten, "European Notions."

96 These were the qualities regularly asked for in the 1930s in advertisements for personnel in Huisorouw in Indië 5, 2 (1936): 131.

97 See: Karel van Wolferen, The Enigma of Japanese Power. People and Politics in a Stateless Nation (New York: Knopf, 1989); a.o. Laura Cooley, "Maintaining Rukun for Javanese Households and for the State," in Women and Mediation in Indonesia, ed. Sita van Bemmelen et al. (Leiden: KITLV Press, Verhandelingen KITLV 152, 1992), pp. 229-48.
} 
